\title{
Corporate liquidity in normal and crisis times: what is the best yardstick?
}

\section{André Bastiaan DORSMAN}

\author{
Vrije Universiteit Amsterdam, The Netherlands \\ Wim WESTERMAN \\ University of Groningen, The Netherlands
}

Received: 07.06.2021, Revised: 18.10.2021, Accepted: 25.10.2021

doi: http://dx.doi.org/10.29015/cerem.927

Aim: This paper is meant to investigate measures that help to assess corporate liquidity in both normal and crisis periods, to find out what matters on corporate liquidity in crisis times.

Design / research methods: We provide an overview of relevant liquidity measures used by both professionals and academics, apply regular liquidity measures on three major European electricity suppliers, study three local cases to find out how the recent COVID-19 crisis affected liquidity and provide an overview of liquidity management on 27 electricity, oil/gas and other multinational firms.

Conclusions / findings: Liquidity measures concentrate on cash ratios, working capital ratios and in specific the cash conversion cycle (CCC). In crisis times, whereas priorities do change, liquidity measures should not. In the COVID-19 crisis, firms go for leaner operations, as well as financing adjustments when needed.

Originality / value of the article: We plead for keeping a close eye on the CCC in both good and bad times. The article provides various recommendations to academics and practitioners.

Keywords: cash, working capital, cash conversion cycle, crisis, liquidity measures.

JEL: G30, M41.

Correspondence address: Wim WESTERMAN, University of Groningen, Faculty of Economics and Business, Landleven 2, 9747 AE Groningen, The Netherlands. E-mail: w.westerman@rug.nl. 


\section{Introduction}

After what was with hindsight just a first wave of the COVID-19 pandemicinduced economic crisis, PwC UK (Windaus et al. 2021) surveyed global working capital practices of large firms. It was shown that during the first half of 2020, their Days of Sales Outstanding (DSO), Days in Inventory (DIO) and Days in Payment Outstanding (DPO) had risen by $15 \%, 18 \%$ and $17 \%$ respectively. The net working capital cycle had increased by five days. This deterioration had not been equalized over the industries though. The automotive sector, the aerospace, defense $\&$ security sector and the energy \& utilities sector were the worst performers, whereas e.g. the pharmaceutical \& life sciences sector unsurprisingly even did better than before. The study called for "Act Now to Recover", but also to prepare for long lag times when recouping, since cash flows would get worse first before being better. This makes it wise to point at warning indicators on liquidity.

On 25 March 2020, in the beginning of the COVID-19 crisis, the daily financial newspaper "Het Financieele Dagblad", published a quick research (Kakebeke, Segenhout 2020), on firms whose shares were included in the leading Dutch stock index AEX. They compared for each AEX company the cash position with the net profit and showed that the ratio cash/net profit varied between 12.43 (Galapagos) to 0.09 for RELX, suggesting that a high ratio means that the company is well equipped to withstand the crisis. Such a conclusion is wrong. Rather than the profit as such, the quality of it matters. In case of Galapagos, the profit was very small and every component related to this small figure looked good. If we may believe the authors, the publisher RELX seemed to be in serious trouble. Just $9 \%$ of the profit of this company was held in cash. Again, such an idea is not helpful. The liquidity measure used, cash/profit, is uncommon in research and reveals an accounting bias in that it is related to profit not cash flows. Moreover, rather than cash, working capital (in a narrow sense) deserves specific attention to assess a firm's liquidity.

The above statement warrants further explanation and requires more in-depth study. In this paper, we will do so in multiple ways. Firstly, we will provide an overview of general liquidity measures used in both practice and academia. It shows that cash or net working capital to sales or assets ratios, as well as operating and 
cash conversion cycles are indeed common types of yardsticks and that performance results found do not differ that much per measure. Secondly, we measure the liquidity of three major Dutch electricity suppliers in various ways. These types of firms are interesting because of their country-specific supply chains and their interconnections with the rest of the economy. It shows that under stable conditions the actual liquidity measure chosen does not really influence the assessment. Thirdly, we have three cases on how normally (abundantly) growing small/medium sized Dutch firms actually managed their liquidity when coping with crisis sales losses and sales volatility. The firms share a comparable supply chain role and age profile, but two are in the energy sector and the other is not. Fourthly, we compare 27 large multinational companies on their liquidity management, quite evenly split on electricity, oil/gas and other firms. It shows that the three types of companies employ various operational and financial strategies to keep their cash levels positive. Working capital considerations provoke intensified operational strategies to manage cash conversion cycles, but also short-term financing and long-term solvency (including dividend payout) policies do matter. In fact, profit considerations played a minor role and showed to be rather an outcome than a yardstick. Overall, we hold that various liquidity measures do matter in non-crisis (normal) and crisis times for electricity, oil/gas and other firms alike, but instead of cash-to-profit, other cash ratios or for that matter working capital ratios, are not the yardsticks that help to draw most interesting conclusions from. We instead suggest practitioners to closely monitor the cash conversion cycle at any time.

Our research question can now be formulated as follows: "Which measures are helpful in assessing corporate liquidity in both normal and crisis times?" We have studied the question by reading academic and practice literature, doing discussions and interviews, and at times giving right-on help with more than ten small firms, as well as studying whereabouts of up to 30 large firms. The research period ends with the first wave of the recent "COVID-19" crisis in the first semester of 2020. To answer our research question, we proceed as follows. Section 2 contains an overview of relevant liquidity measures used by both professionals and academics. Next, in section 3, regular liquidity measures on three major Dutch electricity suppliers are discussed. Then, section 4 provides a description of pre- and in-crisis 
liquidity management of three Dutch trade/service/exploration firms. Section 5 has an overview on 27 large electricity, oil/gas and other multinationals in the same respect. We discuss our study's key findings and implications for research and practice in section 6 .

\section{Liquidity measures: cash and working capital}

A company is liquid when it can meet scheduled commitments with available resources (cf. Vernimmen et al. 2018: 206). Perhaps the oldest liquidity measure of modern times is the cash level ("money in the pocket") in terms of coins and bank notes. Now virtually vanished bank instruments such as checks, promissory notes and bills of exchange are included here too. Whereas observers may speak in terms of "cash", they nowadays readily include current accounts, deposits and liquid investments as well, thus to arrive at what is commonly called "cash and near cash". It makes sense to relate cash levels to activity measures such as sales, working capital or assets, to account for size differences of corporations. The standard literature does so in various ways (cf. Sagner 2014; Ross et al. 2019; Vernimmen et al. 2018) and rules of thumb allow for e.g. $2 \%$ of cash ("one week") to $8 \%$ of cash ("one month"). Cash levels can also be scaled by performance measures such as revenues, margins and interest. However, instead of cash rather cash flow is referred to then, despite of the common term "cash coverage ratio". Remark that observers may refer to cash levels in terms of days instead of amounts, using terms such as cash burn rates and cash turnovers.

When taking a broader perspective, corporate liquidity can be measured in terms of working capital. This may include cash items, but rather refers to the sum of (work in progress and) inventories, accounts receivable and accounts payable, in order to distinguish between cash and working capital. Working capital (gross) equals to current assets and net working capital deducts current liabilities, as is commonly done in practice. Working capital definitions can exclude specific items such as inventories and be dealing with all, some or one of its key elements specifically. As with cash, observers may relate working capital to activities and 
scale it by sales or assets in various ways to account for size differences of firms (cf. Sagner 2014; Vernimmen et al. 2018; Ross et al. 2019). Working capital levels can also be scaled to performance measures such as revenues, margins and interest. Observers may also refer to working capital levels in terms of days instead of amounts, using terms such as working capital turnovers and conversion cycles. The latter have well been used to measure corporate liquidity in modern times (Westerman 2015; Dorsman, Westerman 2019). The operating cycle is the period between the arrival of inventory and the receipt of cash on sales. The cash cycle leaves out the accounts payable period and starts when inventories are paid for. In practice, many refinements can be made (Talonpoika et al. 2016).

Around 1990, one of the present authors was teased by colleagues with a lecture slide titled "Cash management: is there any science?", with "science" referring to statistical research and cash management also covering working capital management. Admittedly there was something into it at the time, but the picture has been changing remarkably, see e.g. Opler et al. (1999), Faulkender and Wang (2006), Aktas et al. (2015), as well as Seifert and Gonenc (2018). Firm-specific factors acknowledged to influence cash and working capital levels include size (larger firms need relatively less liquidity), age and growth (more mature firms may be less liquid), profitability (firms with higher earnings can be relatively less liquid), cash flow riskiness and R\&D expenditures (less volatile firms need less liquidity), capital expenditures/ acquisitions, short/long term leverage and dividend payouts (all being reciprocal with liquidity). Of the above measures, profit is the least helpful one. It is a lousy measure for determining whether the firm can sustain a liquidity shock. Instead, one should look at whether the firm makes money with its operations and digging into the operations to assess their quality is needed. Also, taking a broader look can be useful. General economic factors noted by the literature refer to interest rate levels, sector specifics, governance styles and more. The literature is moreover keen to point out that not a high or low liquidity but rather an optimal level should be targeted at. More liquidity may incur lower costs due to a lower probability on a costly shortage of liquidity and needs an investment with a low or no return that therefore lowers the benefits. The more a firm deviates from its benchmarked optimal liquidity in terms of cash and/or working capital, the less its 
economic (net present) value becomes. In other words, there is a trade-off between liquidity risk and financial returns. Given the short-term nature of liquidity management, issues may especially raise in crisis times.

\section{Measuring the liquidity of electricity firms in pre-crisis times}

Dorsman and Van Montfort (2019) showed that the finance issue is becoming more and more important in the electricity industry. They state that the TSO (Transmission System Operator), who is responsible for balancing the grid (electricity network), in fact acts like a clearinghouse. The BRP's (Balancing Responsible Parties) are in that view the clearing members who fully guarantee the risk position of their clients. In the Netherlands, there are three main clearing members in the electricity market, namely Eneco, E.ON and Vattenfall. The financial strength of these main clearing members is important for the health of the (financial) electricity network in the Netherlands. Below, we study the financial strength of these electricity companies.

In the Netherlands, the electricity market is a day-ahead market. On day $t$ the BRP's have to submit their program for day $t+1$ to TenneT, the Dutch TSO. Futures markets with stocks and bonds as underlying values work with (additional) margins. No margins paid means no deal. That is not the case on the electricity market. The TSO asks only a very small margin that is insufficient when there is a liquidity issue of one of these main clearing members. As long as the liquidity position of a clearing member is not an issue, absence of margins is not directly a problem. However, E.ON and Vattenfall are both facing a large solvency problem. The energy switch from fossil fuels to renewable assets means that those two companies own stranded assets (coal-fired and nuclear plans). The stock price of E.ON was remarkably reduced from $€ 14.46$ (April 14, 2015) to $€ 9.52$ (Dec. 31, 2019), while during this period the DAX (the German stock exchange index) increased from $12,227.60$ to $13,249.01$.

Whereas regular companies have a positive working capital position, trading companies face an issue. Looking at the working capital of the latter, they have very 
limited inventories and their clients have to pay them on a monthly base, while the trade companies themselves pay their obligations after a longer period. In other words, those trade companies have a negative working capital. Another industry with a negative working capital is the retail sector, take for example the Dutch / Belgian firm Ahold Delhaize. In addition, when a regular firm is growing, an additional investment in working capital is necessary, necessitating a cash outflow. However, when the investment in working capital is negative, growth incurs a cash inflow. This can be a reason why clients are "invited" with high discounts to buy the products of the retailers. A higher turnover creates a cash inflow for a retail firm. The old electricity (system) traders are all former state-owned companies and are not used to compete with each other. They created an oligopolistic market structure with a weak competition between the three main (system) traders, E.ON, Vattenfall and Eneco. Nevertheless, a reduction of the turnover can also hit the liquidity position of these trading companies in the same way as the position of the retailers that operate in a more competitive market.

About a decade ago, Nuon was split up in Liander (network) and Nuon (trade). Later, Vattenfall bought Nuon and renamed it after some time. Essent eventually came in the hands of the German firm E.ON, with its network company Enexis being run as an independent firm. Eneco remained independent, it was sold to Mitsubishi in early 2020. Together, Eneco, E.ON and Vattenfall lead the Dutch energy trading sector at a joint market share of more than $80 \%$. In Table 1 below, several balance sheet items of E.ON, Vattenfall and Eneco are compared for the years 2017, 2018 and 2019. The amounts for both E.ON and Eneco are in euro (EUR), with the amounts for Vattenfall being in Swedish kroner (SEK, with 1 SEK $=€ 0.095$ on June 30,2020 ). We added the sales and assets data to make the amounts more comparable. We moreover included cash data and do not see much variation in this respect over time, except for Vattenfall that showed record high investments in electricity grids in 2018. 
Table 1. Inventories (INV), accounts receivable (A/R) and accounts payable (A/P) of E.ON, Vattenfall and Eneco for 2017-2019 (amounts for E.ON and Eneco in million EUR, for Vattenfall in million SEK)

\begin{tabular}{|l|l|l|l|l|l|l|l|l|l|}
\hline & E.ON & & & V-fall & & & Eneco & & \\
\hline Item & 2019 & 2018 & 2017 & 2019 & 2018 & 2017 & 2019 & 2018 & 2017 \\
\hline INV (A) & 1252 & 684 & 794 & 13353 & 13647 & 16687 & 158 & 178 & 58 \\
\hline A/R (B) & 14319 & 5445 & 5781 & 26345 & 26003 & 23437 & 655 & 722 & 650 \\
\hline A/P (C) & 16686 & 7637 & 8099 & 27809 & 29482 & 23872 & 1417 & 1517 & 1224 \\
\hline (A+B-C) & -1115 & -1508 & -1524 & 11889 & 10168 & 16252 & -604 & -617 & -516 \\
\hline & & & & & & & & & \\
\hline Cash & 3602 & 5357 & 5160 & 10,604 & 17094 & 8805 & 537 & 504 & 465 \\
\hline & & & & & & & & & \\
\hline Sales & 41484 & 30253 & 37965 & 16636 & 152091 & 135114 & 4271 & 4100 & 3309 \\
& & & & 0 & & & & & \\
\hline Assets & 98566 & 54324 & 55950 & 45078 & 462608 & 409132 & 5968 & 5763 & 5656 \\
& & & & 0 & & & & & \\
\hline
\end{tabular}

Sources: Annual reports 2018 and 2019 of E.ON, Vattenfall ("V-fall") and Eneco.

The sum of Inventories (INV) plus Accounts receivable (A/R) and minus Accounts payable (A/P) is negative for E.ON and Eneco and positive for Vattenfall ("V-fall"). The reason for a positive value for Vattenfall is that it is not only a trader, but also a producer of energy. Her assets include fossil fuel plants and renewables plants. Eneco on the other side is rather a trader. E.ON was in September 2016 split up in two companies, Uniper and E.ON. The fossil fuel part went to Uniper and the renewables part to E.ON. In other words, the stranded assets went to Uniper. E.ON retained the trading activities and the production facilities of renewables. So, it is still a combination of a trader and a producer. Compared to Vattenfall the focus of E.ON is more on the trading side, while E.ON is compared to Eneco relatively more of a producer.

It is interesting to point at a political risk component here. Take the Vattenfall example. Clients of Vattenfall receive a bill for electricity and gas containing various charges, including an amount for fixed electricity costs (Liander), an amount for variable electricity costs, an amount for fixed gas costs (Liander), as well as an amount for variable gas costs. On average, the Dutch yearly bill exists of 3,100 kWh electricity and $1400 \mathrm{~m}^{3}$ gas. Vattenfall bills her clients $€ 0.20$ for every $\mathrm{kWh}$ 
electricity (including charges), at an electricity price on the market of about $€ 0.02$. For gas, these amounts are $€ 0.80$ respectively $€ 0.03$. The oligopolistic market enables trade companies to make a huge margin. Dutch taxpayers do not realize that they pay large amounts to Stockholm (Vattenfall) and Berlin (E.ON) to compensate depreciations on stranded assets.

\section{In-crisis liquidity: a trading firm, an energy solutions firm and a gas exploration firm}

Case research especially fits when studying a contemporary phenomenon (cf. Yin 2018). Below, we discuss three cases (as of June 30, 2020) on Dutch firms that were highly affected by the COVID-19 crisis. They were selected to fit with the samples as shown above and below, with the case firms' size of operations being relatively small on purpose though. Two firms are in the energy industry and the other elsewhere, at a varying focus on production versus sales/service. Their multinational flavour differs from low to high. Much of the data that was collected can only be obtained when there is a trust relationship between the researcher and the firm. This was established via credible middlemen or long-standing contacts. The firms were willing to cooperate at short notice and were very open to the researchers, with on-site visits, formal and informal talks, as well as interview report notes being involved. Public data accessed via het internet, including company websites, completed the data gathering.

The first case is about an abundantly growing trading firm that lost most of its sales instantly, put the core business on hold, started trading fixed assets quickly and controlled its working capital sharply to maintain a zero cash level. The second case is about a firm developing energy solutions for the real estate sector that had to cope with various activity levels of its customers that eventually also changed much over time. The sales decline and volatility caused the firm to monitor its cash and working capital levels closely. The third case refers to a gas exploration firm witnessing a sizeable drop in demand during the COVID-19 pandemic and before, 
which has hurt its cash position and affected its working capital, but specifically has led to a stronger focus on savings and especially free cash flow.

\section{Zuivelrijck}

Together with a companion, René van der Veen founded Zuivelrijck in 2010. This seemed to be a weird undertaking at the time, especially because both of them had ample experience in the focal business of coffee milk in The Netherlands. As René puts it: "a venture capitalist told that he had never heard such a weird idea: it is a niche product, in a declining market, with one giant player." The Dutch typically drink their coffee with a special cream, but to a declining extent. One firm dominates the market: FrieslandCampina. Whereas production of organic coffee milk might attract some sensitive customers, two small entrants had already experience with this, although none of them produced portion cups. However, with some idealism and a lean business model, with Zuivelrijck acting as a product development and trading company under its own Zuivelrijck branded products, the partners were convinced that the firm would become sustainable.

In the beginning, things were tough. René recalls the first batch: "others saw a pallet with nicely packaged cups of coffee milk, but to me it was working capital". Eventually most of it had to be written off and was used for sampling to prevent waste, but the latter turned out to be a sound marketing investment. The market became willing and grew exponentially later. This repeatedly caused working capital and even cash problems in the firm though, which were met by paying business partners partially no earlier than when receivables were collected and with loans from private persons. Add-on products such as sugar sticks and chocolate milk completed the product portfolio and the firm started making profits, enabling René to buy out his business partner. Whereas growth was still way above double-digit percentages, it was however kept under control by slowing it down. Lastly, the sale of milk foaming machines became a new product line that fitted well with the existing business.

René had anticipated on the crisis by cleaning up his working capital and cash position as much as possible upfront. Yet, the main out-of-home (bars, hotels, etcetera) market dried up from one day to another and declined by $90 \%$ with most 
orders being cancelled instantly. What to do? Of course, Zuivelrijck also put its core business on hold as far as possible and thought to be fair. "It was as if I had to restart all over again", René recalls. While soon finding out that "everyone" had liquidity problems whereas Zuivelrijck was relatively little affected, the firm acted as a "fixed asset" trader in its coffee machines by paying upfront for relatively cheap machines and reselling them fast for little higher prices to various types of customers. "I was looking at my bank account all the time", René comments. And for the rest, Zuivelrijck helped its relations to stay in business and keeping them liquid as well.

"When someone cannot pay he simply cannot", René says, especially referring to the small business partners. On its turn, Zuivelrijck was also helped by customers to stay liquid. Since the company had the wrong industry code, by not being a wholesaler but a supplier to the wholesalers in the out-of-home market, government support could not be counted on. "It would not have been much, but could have created more rest", René feels. However, after almost eight weeks of slow business, the market seemed to be slowly picking up on the sudden news that the out-of-home lockdown would dwindle soon. "Some wholesalers started placing small orders and we also placed new productions", René tells with some relief.

When being asked on his yardsticks, René is very clear. Profit, or for that matter even less dividends or so, is not really a measure in start-up and crisis times and although profit and equity are figures that count in terms of company valuation, operational and financial cash flows are way better even then. Cash flows take into consideration account receivables, account payables and loans positions that affect much of the fate of a company such as Zuivelrijck. Both gross and individual working capital items have to be matched with each other. The cash flow should be able to cover financial obligations and therefore cash at hand becomes the final yardstick. In the end, the very competitive business of Zuivelrijck is margin driven. Margins and cash flows are the two daily measures that René considers, with growth being an important indicator for organization and strategy considerations.

HVE 
Tanju Özel is co-owner and Chief Operating Officer of Huis voor Energie (HVE), which develops energy solutions in real estate. HVE holds and Özel vividly argues that peak load is an issue in national electricity grids. Stock building is therefore necessary and especially long-distance transport is harmful. Smart local grids and ESCo (Energy Service Company) solutions are asked for ${ }^{1}$. HVE can service the transitions needed. Its energy directors partner up to make property energy-resistant for the future, with solar panels, heat pumps, smart meters and more. While still being young but building upon over 20 years of experience, they service real estate companies and real estate administrators, real estate vacancy managers, housing corporations and house owners' associations in the Netherlands and (until recently) Belgium.

Organizations may want to outsource their energy supply and management. If so, HVE can initiate, install and operate the ESCo's. The role of HVE in the ESCo may vary from a start-up phase consultant to a long-term manager and participant in the ESCo. HVE can help with financing the investment needed. No financing nor assets risks have to be taken up by the participants at all, since ESCo's can charge them monthly fees covering management fees, depreciation and financing costs. The typical financial constructions that HVE offers pretty much resemble operating leases, with market value resale prices. "While we are a social firm, HVE's business cases underlie strict net present value requirements", Özel points out.

Ideally, the cash flow generated by one investment would offer the money for the next one. Yet, because of the up-front financing needed and moreover being a growing firm itself, HVE employs external financing from supply chain partners and commercial banks. "It is much like a pick here and a pick there", Özel confirms. He has to accept though that banks go for (consolidated) large volumes. Measures that he monitors include earnings before interest, taxes and amortization (EBITA), debt or equity-to-assets and debt service coverage ratio (DSCR). Next to this, financing

\footnotetext{
${ }^{1}$ An energy service company (ESCo) is a company that is engaged in developing, installing and financing comprehensive, performance-based projects, typically 5-10 years in duration, centred around improving the energy efficiency or load reduction of facilities owned or operated by customers (Vine 2005). For more information about ESCos, see also Kangas et al. (2018), as well as Pätäri and Sinkkonen (2014).
} 
peaks and gaps can be mitigated via HVE's cash position (related to sales) and its current account at the bank. Dividends are not used for this purpose.

With negligible supplies and more accounts receivables than accounts payables from both its project and consulting activities, the net working capital of the newcomer HVE is positive, other than the relatively old and large firms in the electricity sector. It is paramount that timely working capital and cash management is a prerequisite needed to maintain a healthy liquidity then. A company such as HVE takes counterparty risks and has to plan, monitor and track its liquidity positions. Large firms are rather payment condition setters than accepters and small parties may be riskier. A detailed and strict corporate liquidity planning down to even a weekly basis helps in this respect. Also, controls on individual cash and working capital items down to a project basis are made frequently. Moreover, HVE staff stays in regular contact with both suppliers and customers to safeguard a fluent flow of cash flows.

At the start of the COVID-19 crisis, some of the HVE partners, being often small or medium sized, encountered liquidity problems and stretched their activities. While having a financial buffer itself and being only little flexible in downsizing, HVE was keen to renegotiate both account receivables and corresponding account payables conditions, such as to sustain good operating and financial relationships and maintaining a healthy liquidity position. "I looked at the bank account all the time", Özel recalls. He added accounts receivables and payables positions to this. When the situation slowly normalized later, Özel maintained this habit.

\section{Vermilion Energy}

Vermilion Energy Netherlands B.V. belongs to a Canada-based Group of oil and gas firms. In the Netherlands, the firm explorers, develops and operates onshore and offshore natural gas fields. The Dutch head office is located in the seaport of Harlingen, with a technical service unit (also hosting the European head office) in Amsterdam and four main treatment centers that process the gas before it goes into the Dutch grid. Established in 2004, Vermilion Energy Netherlands B.V. holds a number two onshore position in the Dutch market. Both as a Group and in the Netherlands, governance, strategy and performance goals are driven by a 
stakeholder approach. With a defensive asset portfolio, the Dutch unit aims at free cash flows as well as growth to create long-term value. The long-term vision translates into an annual planning that is detailed on a monthly basis for operating and cash management purposes.

The Toronto and New York listed Group has felt the pressure of lowered demand (especially in terms of prices) in the course of the COVID-19 crisis. Its quarterly free cash flow has turned negative and the monthly dividend has been suspended. The Group's cash level has fallen remarkably, also relative to sales and the accounts payable and receivable position have been much fluctuating. Following the fall of commodity prices, the value of derivatives on the balance sheet has risen though. The Group recognizes exacerbated risks on commodity (oil and gas), interest (revolving credit facility) and currency (US dollar and Euro) positions, but financial covenants can be satisfied and the corporate liquidity is not at stake.

Sven Tummers is the Managing Director of Vermilion in the Netherlands. While being the first Dutchman in this job, he maintains regular contacts with Canadian head-office staff, nowadays more virtually than before. Also, weekly unit MT meetings can readily be held virtually. Unfortunately, on-site visits and physical meetings have been hindered by the COVID-19 crisis. Still, personal acquaintance with the 100+ hired staff and beyond is evermore needed and sought for in sometimes unconventional ways. This helps to keep the morale high and to keep running the unit lean, with effective and sensitive market responses.

Vermilion witnessed a combination of factors hitting the gas market by early 2020, such as gradually but deep falling natural gas futures prices, cheap LNG transshipments via the Dutch port of Rotterdam and US/EU tensions on the almost completed Nord Stream 2 Baltic Sea gas pipeline. It must however be noted that operations and investments in the oil sector can be stretched less easily than in the gas sector. Operational expenditures (OPEX) and capital expenditures (CAPEX) are curtailed vividly. "All eyes on cash flow management", Tummers says. Safety, health and environmental standards are always prioritized, however.

While financial risk management and cash management are done by the Group, the Dutch unit is involved in discussions about this. Working capital management is an issue in terms of occasional receivings and payments timing, but general accounts 
receivables and accounts payables policies have not been changed lately. However, the unit's focus did alter. Whereas Earnings before Interest, Taxes, Depreciation and Amortization (EBITDA) is still a base performance measure and trade-offs on internal dividend payouts versus capital investments remain important, "barrels" (read: volumes and sales) have given way to "funds" (free) cash flows.

\section{Liquidity of electricity, oil/gas and other multinational firms in the COVID- 19 crisis}

In section 4, we described the whereabouts of three small to large sized Dutch firms serving the local market during (the first wave of) the COVID-19 crisis. We did so by relying upon both public and non-public information. We also studied the fare of 28 large firms that were supposed to have been hurt by the consequences of the pandemic. Indeed, almost all of them experienced a demand breakdown. One of firms, a financial company that was surprisingly little hurt, was assured anonymity. This left us with 27 almost all multinational firms from various sectors. Apart from the others (10), the oil/gas (10) and electricity firms (7) stand out. It must be noted that the distinction made between the latter two industries is somewhat fluent.

Table 2a. Liquidity of electricity sector companies during the COVID-19 crisis (as of June 30, 2020)

\begin{tabular}{|l|l|l|l|}
\hline Name company & Nationality & Crisis effect & Specific remarks \\
\hline Enexis & Dutch & limited & share price?, debt costs?, dividend fine \\
\hline Engie & French & moderate & business lines affected, dividend stop \\
\hline E.ON & German & limited & share price falls, debt costs up, dividend up \\
\hline Greenchoice & Dutch & unknown & disruptive market, debt costs?, dividend? \\
\hline National Grid & British & limited & U.S. business affected, no dividend cut \\
\hline RWE & German & limited & share price falls, debt costs up, dividend up \\
\hline Vattenfall & Swedish & moderate & cash falls, debt costs up, dividend cut \\
\hline
\end{tabular}

Source: authors' own elaborations.

We provide a general overview on the electricity firms first. Interestingly, two firms from section 3 (E.ON and Vattenfall) are sampled here as well. They do not 
stand out though. Showing very timely data, Vattenfall seems to be affected by the COVID-19 crisis the most, given its cash shortfall. It must be noted though that its liquidity position was already deteriorating before, following unusual electricity grid investments. All of the studied firms seem to have been hurt by financial problems with their customers. This affects their debt position and dividend cuts are occasionally found in the business. Notably, the dividend of RWE is even intended to rise however. The difference may be due to the turnaround that RWE has just gone through. The relative corporate emphasis on sales versus production may also account for inter-firm variety. Lastly, public data on Greenchoice (joint venture) and Enexis (non-listed firm), are limited and conclusions must be drawn with care.

Table 2b. Liquidity of oil/gas sector companies during the COVID-19 crisis (as of June 30, 2020)

\begin{tabular}{|l|l|l|l|}
\hline Name company & Nationality & Effect crisis & Specific remarks \\
\hline Baker Hughes & American & limited & CAPEX cut, debt costs /dividend stable \\
\hline BP & British & moderate & assures liquidity, dividend cut 2019 \\
\hline Chevron & American & moderate & CAPEX/OPEX cut, debt ratio/dividend OK \\
\hline ENI & Italian & moderate & supplies rise, share buyback limited \\
\hline ExxonMobil & American & moderate & loss Q1, OPEX/CAPEX cut, dividend stable \\
\hline Fugro & Dutch & moderate & assuring liquidity, OPEX cuts, no dividend \\
\hline Royal Dutch Shell & Dutch & moderate & CAPEX/OPEX cut, buyback/dividend cut \\
\hline Sasol & S. African & moderate & "bad" project, production cut, high debt \\
\hline SBM Offshore & Dutch & limited & "safe" business model, financials sound \\
\hline Total & French & limited & finance/dividend sound, future unsure \\
\hline
\end{tabular}

Source: authors' own elaborations.

As with the electricity sector, all of the oil/gas companies studied do suffer from the COVID-19 crisis. They namely curtail operating costs and capital expenditures. As to their liquidity, the firms keep a close eye. Although changes were noted, it seems as if positions were already at desired levels. Unsurprisingly, downstream firms suffered more than upstream firms that may also have a leaner business model. Having said this, it must be noted that comparable firms, such as Shell and BP on 
one hand versus Chevron and ExxonMobil on the other hand, fare differently. This seems to be due to their financial position at the start of the crisis and not to their varying home base (Europe versus USA). Furthermore, oil and gas bear market prices do also impact on the sector. Lastly, it must be noted that Baker Hughes, Fugro and SBM Offshore are subcontractors. Interestingly, in early March, just before the COVID-19 crisis struck, Fugro placed new shares. The crisis then halved the share price. A bond issue came just too late support the ill-fated capital structure. It had to be withdrawn by the firm.

Table 2c. Non-energy sector companies' liquidity during the COVID-19 crisis (as of June 30, 2020)

\begin{tabular}{|l|l|l|l|}
\hline Name company & Nationality & Effect crisis & Specific remarks \\
\hline Air France - KLM & French & severe & cash burn, capacity cut, gov't support \\
\hline Ajax & Dutch & moderate & financial base OK, sales down, costs cuts \\
\hline Apple & American & negligible & financials sound, dividend/buybacks up \\
\hline Boeing & American & moderate & "blow”, loss, bond flotation, dividend cut \\
\hline Heineken & Dutch & moderate & bond flotations, bonus/dividend cut \\
\hline Lufthansa & German & severe & asset/cost/dividend cut, gov't support \\
\hline ING & Dutch & moderate & less profit, supports clients, dividend cut \\
\hline Philips & Dutch & limited & profit falls, financials OK, stock dividend \\
\hline Randstad & Dutch & moderate & fin. base sound, cost/bonus/dividend cut \\
\hline Royal Flora Holland & Dutch & moderate & loss, bank facility, supply chain financing \\
& & & \\
\hline Source: authors' own & & &
\end{tabular}

Source: authors' own elaborations.

The table above shows remarkable differences. Unexpected by even itself, the U.S. hardware and software firm Apple was hardly hurt by the COVID-19 crisis, whereas e.g. the Dutch health care and consumer products firm Philips was affected. Business went even worse with airline and aircraft firms alike, but it must be noted that Boeing was already suffering from a safety crisis. Anyway, subsequent the pattern was much the same: firms pressed costs and investments, lowered asset bases, did away with (cash) dividend and share buyback (if being around), borrowed money or had to lend it and even went for government support (airline firms). 
Interestingly, bonuses seemed to be cut only case-wise. Here and there, rather hesitatingly, shareholders indicated to be willing to step in for help.

\section{Conclusion and recommendations}

From the above, our research question on helpful liquidity measures can be answered in a very basic way. Corporate liquidity can be assessed with any decent measure shown in the literature. Yet, some measures are better than others are and some may be even misleading. To start with the latter: book measures confuse, especially when not being real-time. When the first wave of the COVID-19 crisis began, all of the studied firms showed (pretty) healthy balance sheet and income statement positions. Whether net working capital was negative or positive did not matter, as long as actual cash levels were fine, as they most likely all were. Under such circumstances, it does not matter much whether a firm monitors accounting stocks or market value stocks, profits or cash flows, in- and output or actual throughput.

But in crisis situations, all may be different. The baseline of a crisis is normally that account receivables positions swallow whereas cash positions dwindle at the same time. Traditional accounting measures such as cash/sales or cash/assets become pretty useless then, since the first may even go up because of falling sales and the latter may be (with net assets: close to) stable. Profits are quite unaffected when a company has a high operating leverage, but cash levels may fall sharply as long as accounts payables positions do not drop in tandem. Book measures do not point quickly at operational and financial reconsiderations needed. They do not take into account actual cash levels and may ignore timely supply chain issues.

The small/medium-sized local case firms studied knew this. Whereas they do partially reason in accounting terms (in terms of equity and profits) for convenience reasons, they quickly adapt to actual cash levels and cash flows as soon as problems in the supply chain emerge. Account receivables and account payables are tightly linked to each other, as is done with account payables and inventories. It is 
understood that cash levels are supported when working capital levels are subdued and dividend cuts may do well too (Snijders et al. 2009).

The baseline with the 27 firms studied was that they had to maintain a rockbottom liquidity base. Whereas some of the firms seemed to have a liquidity and solvency buffer (by accident or on purpose), others were less likely to be in a favorable start position and needed help. The issue of which liquidity measure to look at appears to be largely redundant under such circumstances. Whether focusing on sales, profits, cash flows, cash burns or whatever does not seem to matter. Or does it? Remarkably, some firms seem to fare better than others. Is operational flexibility doing the job? Then it might also be that focusing on operations-type of measures is asked for, which calls for using conversion cycles as key financial yardsticks.

Corporate liquidity is twinned with corporate finance, making the financial supply chain perform its linking job. Corporate finance is by action equalized to corporate investment. Cash in and cash out are aligned to strengthen the operational supply chain. In other words: the cash conversion cycle (CCC) is focused upon then. When the CCC drives corporate liquidity, operations are viewed with a liquidity lens. The three case firms thus go for ever leaner operations, with operational throughput measures being top of mind.

The 27 multinational firms sampled may have sensed the above as well, since there is much awareness of supply chain issues nowadays. Nevertheless, more than half of them were found trapped in a liquidity crisis, pretty much regardless their industry (oil/gas, electricity, or other). This may be due to their low operating leverage, but this does not distinguish them much from companies that feel less liquidity pressure. A positive net working capital position induced by the business model does also not really set these companies apart. Nevertheless, many had to cut down on planned dividend payouts, share repurchases and bonuses, whereas some needed bank loan or owner's equity support.

To sum up the conclusion, our research question was: "Which measures are helpful in assessing corporate liquidity in both normal and crisis times?" With just little exaggeration, the answer could be: "pick the cash conversion cycle and delve into its base constituting parts: accounts receivables, accounts payables and 
inventories". The hick-up is though, that circumstances may also ask for nonoperational measures that are related to short-term and even long-term financing. Especially firms that are financed sharply or whose supply chains are hurt most may need to resort to this.

This brings us to our recommendations. It is tempting to view the COVID-19 crisis as both a liquidity crisis and again a financial crisis, this time due to nonfinancial firms being serviced with "sharp" financing. It is striking to note that the solvency went down with some of the sampled firms before the COVID-19 crisis started, or that they had (also) a relatively high share repurchase level, whereas with some of them bonuses were also found to be sizeable. In that sense, efforts of e.g. the Dutch government to (further) cut down on debt financing advantages can be supported. Maybe it is worthwhile to reintroduce share repurchase taxes, to prevent firms from being tempted to lower equity levels this way. Lastly, all of this may be linked to sound solvency and liquidity requirements. Government should not bail out greedy owners (again).

Governments can set fitting regulations however, not just on levels of solvency and liquidity requirements, but also on how these can be met in a decent way. An example is on payment conditions, which refer to issues such as due times, discount terms and interest rates. During the COVID-19 crisis, it has become clear that many firms have been willing to be flexible and it is advisable to develop sound supply chain customs that support such behavior. However, since negotiation bases between especially large and small companies may differ much, it is paramount that obligations due are paid for as soon as possible and reasonable. The plans of e.g. the Dutch government to reduce payment times to at most 30 days can be welcomed.

Having said this, it is most important that companies should take their own responsibility to safeguard their liquidity with real-time measures. In a recent contribution, Deegan (2020) points at the usefulness of cash flow dashboards that display reporting and forecast data that are related to key financial performance indicators (KPI's). Five metrics generally take a central position: the cash walkthrough that depicts the steps from an opening balance to a closing balance, consolidated actual and forecast cash positions, the total actual and forecast available liquidity, net debt and covenants, as well as actual versus forecast 
differences and variances. Such a list may especially help large firms and may have to cover additional fields.

For example, even more recently, McKinsey \& Company (Grube et al. 2020) has published a list of monthly KPI's for CFO's that takes on board COVID-19 crisis lessons learned. An array of working capital (A/R, A/P and inventory), CAPEX, OPEX and balance sheet items are featuring here. Also, the cash conversion cycle is referred to explicitly. Liquidity goes beyond cash and even beyond working capital. Therefore, taken together, the two lists would or should ring a bell with both the local and multinational companies in our study. However, firms may want to use and adapt such checklists for their own purposes, we feel.

Strangely, the above-listed issues are not well-studied. Also, our study is only explorative, although we have taken on board experiences from multiple companies and advisories. Our sample was by no means meant to be statistically representative. However, we did strive for analytical representativeness: finding out what matters on corporate liquidity in crisis times. Whereas it must be noted that our research does not go beyond the first semester of 2020, with a new COVID-19 wave globally speeding up just a quarter later and still being around a year later, we do not feel that our initial views will be challenged much. Nevertheless, further study is advisable.

Actual liquidity measures used and their relative importance cannot be drawn from annual reports. Whereas tough econometrical modelling may be useful in the end, baseline of the research input will be data that have to be supplied by firms. We however feel that they may be much willing to do so, with the support that we have had for this study by a wide range of practitioners already indicating this, especially when a trusted two-way relationship exists. Nevertheless, the type of (30+ firms) case survey study that comes to fore then costs much time. Having said this, a broad research coalition may take some of the barriers away. And even if not, we hope that stubborn researchers do take up such a study anyway. Also, the methodology of Aktas et al. (2015), who study with statistical techniques excess working capital to look for optimums, may be helpful for further econometrical study in this respect, that is: as soon as time permits and not just because it would be more "scientific".

Meanwhile, firms will have learned from the COVID-19 crisis and take more precaution. To help with a very basic rule of thumb advice, we give them in 
consideration to double their rock bottom limits on cash, working capital and solvency. While this may be overdoing for many firms, it is also relatively cheap to do so, at least nowadays. New optimums can be sought for by stumbling in the dark and building up experience to arrive at acceptable solutions at first, but artificial intelligence systems such as increasingly applied in treasury management may do a better job in the end (Polàk et al. 2020). Having said this, we feel that proper sensing will still be needed anyway.

\section{Acknowledgements}

The authors thank René van der Veen, CEO/owner of Zuivelrijck, Tanju Özel, CTO of HVE and Sven Tummers, managing director of Vermilion Energy Netherlands, for sharing their insights and company data. We thank students of the University of Groningen for helping with collecting data. Special thanks go to Mark Schouten (VU University, Amsterdam), who was involved in an early stage of the study. Johan van Ophem and Katarzyna Kurek (both Wageningen University, the Netherlands) both reviewed paper drafts and participants at the $14^{\text {th }}$ ISINI conference (September 2020, Poland) and the $8^{\text {th }}$ CEVI conference (May 2021, Belgium) provided comments. All errors and omissions are of course our own.

\section{Glossary}
$\mathrm{A} / \mathrm{P}$
Accounts Payable
$\mathrm{A} / \mathrm{R}$
Accounts Receivable
BRP
Balancing Responsible Parties
CAPEX
Capital expenditures
CCC
cash conversion cycle
DAX
DIO
Deutscher Aktienindex (the German stock exchange index)
DPO
Days in Inventory
DSCR
Days in Payment Outstanding
DSO
Debt service coverage ratio
EBITA
Days of Sales Outstanding
EBITDA
Earnings before interest, taxes and amortization
ESCo
Earnings before interest, taxes, Depreciation and amortization
INV Energy Service Company
Inventories 


$\begin{array}{ll}\text { KPI } & \text { Key finance performance indicators } \\ \text { LNG } & \text { Liquid natural gas } \\ \text { MT } & \text { Management team } \\ \text { OPEX } & \text { Operational expenditures } \\ \text { SEK } & \text { Svensk Krona (the currency of Sweden) } \\ \text { TSO } & \text { Transmission System Operator }\end{array}$

\section{Bibliography}

Aktas N., Croci E., Petmezas D. (2015), Is Working Capital Management Value-Enhancing? Evidence from Firm Performance and Investments, "Journal of Corporate Finance", vol. 30(C), pp. 98-13.

Deegan C. (2020), The Necessity of Real-Time Cash Flow Dashboards, The Global Treasurer, August 13, https://www.theglobaltreasurer.com/2020/08/13/ [05.12.2021].

Dorsman A.B., van Montfort C.A.G.M. (2019), The Grid: From a Technical to a Finance Issue. Who Bears the Financial Risk?, Working Paper, Free University Amsterdam, May.

Dorsman A.B., Westerman W. (2019), What Drives Working Capital Levels?, "Hacettepe University Journal of Economics and Administrative Sciences", vol. 37 no. 1, pp. 41-63.

Faulkender M., Wang R. (2006), Corporate Financial Policy and the Value of Cash, "The Journal of Finance", vol. 61 no. 4, pp. 1957-1990.

Grube C., Park S.-Y., Rüden J. (2020), Moving from Cash Preservation to Cash Excellence for the Next Normal, McKinsey Corporate Finance Practice, September, https://www.mckinsey.com/businessfunctions/strategy-and-corporate-finance/our-insights/moving-from-cash-preservation-to-cashexcellence-for-the-next-normal [05.12.2021].

Kakebeeke P., Segenhout J. (2020), AEX bedrijven kunnen eerste klap van de coronacrisis goed zelf opvangen, "Het Financieele Dagblad", March 25.

Kangas H., Lazarevic D., Kivimaa P. (2018), Technical Skills, Disinterest and Non-functional Regulation: Barriers to Building Energy Efficiency in Finland Viewed by Energy Service Companies, "Energy Policy", vol. 114(C), pp. 63-76.

Opler T., Pinkowitz L., Stultz R., Williamson R. (1999), The Determinants and Implications of Corporate Cash Holdings, "Journal of Financial Economics", vol. 52 no. 1, pp. 3-46.

Pätäri S., Sinkkonen K. (2014), Energy Service Companies and Energy Performance Contracting: Is There a Need to Renew the Business Model? Insight from a Delphi Study, "Journal of Cleaner Production", vol. 66 no. 1, pp. 264-271.

Polàk P., Nelischer C., Guo H., Robertson D.C. (2020), "Intelligent" Finance and Treasury Management: What We Can Expect, “AI \& Society”, vol. 35 no. 2, pp. 715-726. 


\section{André DORSMAN, Wim WESTERMAN}

Ross S., Westerfield R.W., Jaffe J. (2019), Corporate Finance, $12^{\text {th }}$ edition, McGraw-Hill Education, New York.

Sagner J.S. (2014), Working Capital Management: Applications and Cases, John Wiley \& Sons, Hoboken, NJ.

Seifert B., Gonenc H. (2018), The Effects of Country and Firm-Level Governance on Cash Management, "Journal of International Financial Markets, Institutions \& Money”, vol. 52, pp. 1-16.

Snijders B., Gonenc H., Westerman W. (2009), On Dividends and Share Return: Dividend Cuts Help in Crisis Outbreaks, "Journal of Corporate Treasury Management", vol. 3 no. 1, pp. 8-10.

Talonpoika A., Kärri T., Pirttilä M., Monto S. (2016), Defined Strategies for Financial Working Capital Management, "International Journal of Managerial Finance", vol. 12 no. 3, pp. 277-294.

Vernimmen P., Quiry P., Dallochio M., Le Fur Y., Salvi A. (2018), Corporate Finance: Theory and Practice, $5^{\text {th }}$ edition, Wiley, Hoboken, NJ.

Vine E. (2005), An International Survey of the Energy Service Company (ESCO) Industry, "Energy Policy", vol. 33 no. 5, pp. 691-704.

Windaus D., Rosier H., Brady A. (2021), Working Capital Study 20/21: Act Now to Recover, PwC UK.

Westerman W. (2015), Working Capital Management Programs: Yesterday, Today, Tomorrow, "Journal of Modern Accounting and Auditing", vol. 11 no. 4, pp. 210-217.

Yin R.K. (2018), Case Study Research and Applications: Design and Methods, 6th ed., Sage, Thousand Oaks, CA. 